\title{
PEMERIKSAAN KESEHATAN MASYARAKAT YAPASE, DISTRIK DEPAPRE, PAPUA
}

\author{
HEALTH EXAMINATION OF YAPASE PEOPLE, DISTRICT DEPAPRE, PAPUA \\ ${ }^{1)}$ Eva Susanty Simaremare, ${ }^{2}$ Septriyanto Dirgantara, ${ }^{3)}$ Elsye Gunawan, ${ }^{4)}$ Rani Dewi \\ Pratiwi, ${ }^{5}$ Rusnaeni \\ ${ }^{1,2,3,4,5)}$ Program Studi Farmasi-Jurusan Biologi FMIPA Universitas Cenderawasih \\ Jl. Kampwolker Perumnas III Waena Jayapura \\ email: eva_smare@yahoo.com
}

\begin{abstract}
ABSTRAK
Tekanan darah tinggi, diabetes mellitus (DM), asam urat, dan kolesterol merupakan penyakit yang semakin lama namun pasti akan menyebabkan kesakitan yang tidak tertahankan bahkan menimbulkan kematian pada penderita. Tujuan kegiatan ini adalah 1. Melakukan pemeriksaan meliputi tekanan darah, gula, asam urat, dan kolesterol; 2. Menganalisis potensi kesehatan masyarakat kesehatan di Kampung Yapase. Kegiatan ini dilakukan dengan metode pemeriksaan langsung pada peserta kegiatan dan edukasi mengenai hasil pemeriksaan. Kegiatan ini diselenggarakan pada hari kamis tanggal 3 Agustus 2017 di Aula Desa Yapase. Hasil yang diperoleh dari kegiatan yaitu jumlah peserta sebanyak 32 orang. Dari hasil pemeriksaan tekanan darah tekanan darah, 9 orang (28\%) mengalami hipertensi. Pada pengukuran asam urat diperoleh 18 orang (56\%) memiliki kadar asam urat yang tinggi.
\end{abstract}

Kata kunci: Kesehatan, tekanan darah, asam urat, Yapase

\section{ABSTRACT}

High blood pressure, diabetes mellitus, uric acid, and cholesterol are diseases that will surely cause unbearable pain until death. The purpose of this activity are 1. Examinating the value of blood pressure, glucose, uric acid, and cholesterol people; 2. Analysing the potential diseases that caused from the fourth examination in Kampung Yapase. This activity was conducted by practice determination method used Glucosel Uric Acid, Cholesterol (GCU) apparatus and educate participans about the result of examination. It is was held on Thursday 3 August 2017 at Yapase Hall. Results showed that participants was 32 people. The blood pressure examination, 9 people (28\%) have hypertension. On the measurement of uric acid obtained 18 people (56\%) have high uric acid levels.

Keywords: Health, Blood Preasure, Uric Acid.

Submited : 10 April 2017 Revision : 20 Juni 2017 Accepted : 9 September 2017

\section{PENDAHULUAN}

Tekanan darah tinggi, diabetes mellitus (DM), asam urat, dan kolesterol merupakan penyakit yang semakin lama namun pasti akan menyebabkan kesakitan yang tidak tertahankan bahkan menimbulkan kematian pada penderita. Tekanan darah yang tinggi akan menimbulkan hipertensi dan jika menetap akan menimbulkan trauma langsung terhadap dinding pembuluh darah arteri koronaria, sehingga memudahkan terjadinya arterosklerosis (penyempitan pembuluh darah arteri) yang merupakan penyebab PJK (Penyakit Jantung Koroner) (Charles dkk, 2016).

DM merupakan penyakit kronik walau secara tidak langsung menyebabkan 
Pemeriksaan Kesehatan Masyarakat Yapase, Distrik Depapre, Papua

kematian tetapi jika tidak dikelola secara tepat dapat berakibat fatal (Dinkes RI, 2005). Gagalnya response sel-sel terhadap insulin akan menyebabkan sistem metabolisme tubuh rusak oleh karena asupan gula tidak dapat diubah dan disimpan baik dalam hati, otak, atau otot.

Penyakit asam urat terjadi karena gangguan metabolik dimana jumlah asam urat dalam tubuh tidak normal sehingga akan menyebabkan pembengkakan pada persambungan otot-otot (ogut). Asam urat akan berkembang menjadi gangguan ginjal, hipertensi, hiperlipidemia, kanker, diabetes, dan kegemukan (Tayeb dkk. 2012; Hayani dan Widyaningsih, 2012).

Penyakit kolesterol adalah penyakit dimana tingkat kolesterol dalam darah melampaui kadar yang normal. Kolesterol berlebih dapat tertimbun di dalam dinding pembuluh darah dan menimbulkan penyempitan atau pengerasan pembuluh darah (ateroskleorosis). Kolesterol dapat menyebabkan stroke dan pasien dapat mendadak meninggal karena serangan jantung atau penyumbatan pembuluh darah (Setiasih dan Marfianti, 2014).

Sulitnya pengobatan penyakit ini dengan waktu yang singkat, mengharuskan para masyarakat untuk sejak dini diedukasi sebagai aktifitas preventif untuk mengurangi kematian. Penyebab terjadinya penyakit ini kebanyakan disebabkan karena pola hidup yang tidak sehat seperti kurang aktifitas bergerak (olahraga) dan kurang mengontrol makanan sehat (konsumsi sembarangan).

Kondisi mitra yang ditargetkan juga dipengaruhi pola hidup/ kebiasaan masyarakat seperti merokok dan minum miras, minimnya pengetahuan kesehatan, topografi dan akomodasi wilayah Yapase yang sulit dijangkau, dan layanan kesehatan rumah sakit tidak ada. Melihat keadaan ini maka tujuan dari kegiatan ini melakukan pemeriksaan dengan cepat bagaimana kondisi kesehatan masyarakat di Yapase.

\section{METODE}

Metode yang digunakan dalam kegiatan ini meliputi penyuluhan yang dilanjutkan dengan demonstrasi pemeriksaan kesehatan, dan diskusi grup tentang konseling, informasi, dan eduasi.

Tahapan dalam kegiatan yaitu sebagai berikut:

1. Perencanaan dan persiapan

Tim pelaksana berkoordinasi dengan pihak mitra dalam hal ini kepala kampung mengenai peserta, waktu, tempat dan susunan acara kegiatan. Selanjutnya tim pelaksana mempersiapkan alat dan bahan yang digunakan dalam kegiatan. Persiapan ini difokuskan dengan menyiapkan semua media dan perlengkapan yang dibutuhkan untuk melaksanakan kegiatan ini.

2. Sosialisasi kegiatan

Sosialisasi dilaksanakan untuk memberikan pengumuman kepada masyarakat kampung tentang pemeriksaan yang akan dilaksanakan.

3. Pemeriksaan kesehatan

Kegiatan dilakukan dengan cara mengukur berat badan (BB), memeriksa tekanan darah, kadar gula darah, asam urat, dan kolesterol dilanjutkan dengan konsultasi hasil secara bergilir

Pemeriksaan dilaksanakan dengan menggunakan alat test dgital. Masyarakat yang datang dicatat identitasnya (nama, umur, jenis kelamin, pekerjaan, dan pendidikan terakhir) lalu dipersilahkan menuju meja pemeriksaan. Masyarakat yang telah diperiksa berat badan (BB), memeriksa tekanan darah, kadar gula darah, asam urat, kolesterol lalu diberikan kertas hasil pemeriksaan untuk konsultasi bersama pakar secara dua arah. 


\section{HASIL DAN PEMBAHASAN}

Kegiatan pengabdian pemeriksaan berat badan (BB), memeriksa tekanan darah, kadar gula darah, asam urat, kolesterol dan konsultasi hasil telah dilakukan kepada 32 orang masyarakat Kampung Yapase Distrik Depapre. Peserta yang mengikuti kegiatan ini dapat diklasifikasikan dari jenis kelamin, usia, pekerjaan, pendidikan, dan umur. Peserta yakni ada 25 orang perempuan dan 6 orang laki-laki dimana dari peserta perempuan didominasi IRT dan laki-laki sebagai nelayan. Persentase pendidikan penduduk Yapase didominasi SD. Rentang usia peserta yang mengikuti pengabdian ini adalah usia 20-82 tahun seperti pada tabel 1 . Tabel 1. Data peserta dalam pemeriksaan kesehatan masayarakat Yapase

\begin{tabular}{|l|c|r|}
\hline Jenis Kelamin & \multicolumn{2}{c}{ Jumlah } \\
\hline Perempuan & 26 & $81,3 \%$ \\
\hline Laki-laki & 6 & $18,8 \%$ \\
\hline & \multicolumn{2}{|c|}{ Jumlah } \\
\hline Usia & 2 & $6,3 \%$ \\
\hline $20-30$ & 5 & $15,6 \%$ \\
\hline $31-40$ & 11 & $34,4 \%$ \\
\hline $41-50$ & 7 & $21,9 \%$ \\
\hline $51-60$ & 7 & $21,9 \%$ \\
\hline >60 & \multicolumn{2}{|c|}{} \\
\hline & \multicolumn{2}{|c|}{ Jumlah } \\
\hline Pekerjaan & 4 & $12,5 \%$ \\
\hline Guru & 17 & $53,1 \%$ \\
\hline IRT & 2 & $6,3 \%$ \\
\hline Nelayan & 1 & $3,1 \%$ \\
\hline Pendeta & 1 & $3,1 \%$ \\
\hline Pensiun & 5 & $15,6 \%$ \\
\hline Petani & 1 & $3,1 \%$ \\
\hline PNS & 1 & $3,1 \%$ \\
\hline Polisi & & \\
\hline & & $21,9 \%$ \\
\hline Pendidikan Terakhir & \multicolumn{2}{|c|}{ Jumlah } \\
\hline SD/ STR & 14 & $43,8 \%$ \\
\hline SMP & 3 & $9,4 \%$ \\
\hline SMA & 8 & $25,0 \%$ \\
\hline Perguruan Tinggi & 7 & 21 \\
\hline
\end{tabular}

Dari hasil pencatatan pemeriksaan tekanan darah, didapatkan nilai tekanan darah sistol tertinggi sebesar $198 \mathrm{mmHg}$ dan nilai terendah $88 \mathrm{mmHg}$ dan nilai ratarata 128,6. Nilai tekanan darah diastol tertinggi sebesar $98 \mathrm{mmHg}$, nilai terendah $57 \mathrm{mmHg}$ dan nilai rata-rata 75,2 . Nilai kadar glukosa dalam darah yang tertinggi sebesar $159 \mathrm{mg} / \mathrm{dl}$, nilai terendah $65 \mathrm{mg} / \mathrm{dl}$ dan nilai rata-ratanya $100,1 \mathrm{mg} / \mathrm{dl}$.

Pada pemeriksaan, sebanyak sejumlah 13 orang $(41 \%)$ memiliki tekanan darah normal, 10 orang (31\%) berpotensi prehipertensi, dan 9 orang (28\%) mengalami hipertensi. Sedangkan pada pemeriksaan kadar gula darah 6 orang (19\%) perserta memiliki gua darah yang rendah dan 26 orang $(81 \%)$ dalam keadaan normal. Pada pengukuran kolesterol darah, didapatkan 2 orang (6\%) memiliki kadar kolesterol yang tinggi dan 30 orang (94\%) memiliki kadar kolesterol yang normal dalam kondisi normal. Pada pengukuran asam urat diperoleh 3 orang (9\%) memiliki kadar asam urat yang rendah, 11 orang (34\%) memiliki kadar asam urat yang normal dan 18 orang (56\%) memiliki kadar asam urat yang tinggi.

Pada kegiatan pengabdian ini, data yang diperoleh menunjukkan bahwa masyarakat kampung Yapase secara umum memiliki kondisi kesehatan yang baik. Rata-rata nilai pemeriksaan berada pada keadaan normal. Akan tetapi pada pemeriksaan tekanan darah dan asam urat masyarakat, tekanan darah $31 \%$ hipertensi dan $56 \%$ memiliki kadar asam urat yang tinggi.

Jika dilihat kondisi kesehatan penduduk Yapase berdasarkan usia, jumlah peserta dengan usia $<50$ tahun sebanyak 18 orang $(56 \%)$ dari total 32 peserta dan $>50$ tahun 14 orang $(34 \%)$. Pada usia $<50$ tahun dengan jumah peserta 18 orang, 1 orang (6\%) menderita tekanan darah tinggi (hipertensi), 11 orang (61\%) menderita kadar asam urat di atas normal, dan 1 orang (6\%) memiliki kadar kolesterol tinggi. Pada usia $>50$ tahun terdapat 14 orang (34\%) dari total 32 peserta, 6 orang $(43 \%)$ menderita 
tekanan darah tinggi, 7 orang $(23,33 \%)$ menderita kadar glukosa di atas normal, 8 orang $(43 \%)$ menderita kadar asam urat di atas normal, dan 1 orang (7\%) menderita hiperkolesterolemia Pada pemeriksaan tekanan darah, gula, dan kolesterol umumnya golongan peserta dengan usia di atas 50 tahun lebih tinggi daripada peserta dengan usia di bawah 50 tahun. Faktor umur merupakan salah satu yang dapat

\begin{tabular}{|c|c|c|c|c|c|c|c|c|}
\hline \multirow{3}{*}{$\begin{array}{l}\text { Tingkatan } \\
\text { pengukuran }\end{array}$} & \multicolumn{2}{|c|}{ Tekanan Darah (mm Hg) } & \multicolumn{2}{|l|}{ 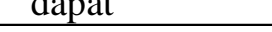 } & \multicolumn{2}{|c|}{ Asam Urat (mg/dl) } & \multicolumn{2}{|c|}{ Kolesterol (mg/dl) } \\
\hline & \multicolumn{2}{|c|}{$\begin{array}{c}\text { hipertensi: }>140 / 90 \text {; prehipertensi: } \\
\text { 120/80; normal: }<120 /<80\end{array}$} & \multicolumn{2}{|c|}{$\mathrm{DM}>200$} & \multicolumn{2}{|c|}{ Pria: 3,6-8,5; wanita: 2,3-6,6 } & \multicolumn{2}{|c|}{$<200$} \\
\hline & $<50$ tahun & $>50$ tahun & $<50$ tahun & $>50$ tahun & $<50$ tahun & $>50$ tahun & $<50$ tahun & $>50$ tahun \\
\hline di atas & $6 \%$ (hipertensi) & $43 \%$ & $0 \%$ & $0 \%$ & $61 \%$ & $43 \%$ & $6 \%$ & $7 \%$ \\
\hline normal & 17\% (Prehipertensi) & $57 \%$ & $83 \%$ & $100 \%$ & $22 \%$ & $36 \%$ & $94 \%$ & $93 \%$ \\
\hline dibawah & $78 \%$ (normal) & $0 \%$ & $17 \%$ & $0 \%$ & $17 \%$ & $21 \%$ & $0 \%$ & $0 \%$ \\
\hline
\end{tabular}

Sesuai standar yang dikeluarkan oleh pemerintah mengenai gangguan tekanan darah (hipertensi >140/90; pre hipertensi 120/80; nornal <120/80 mm Hg); GDA $\mathrm{DM}>200$; asam urat pria 2,6-8,5; wanita 2,3-6,6 mg/dl, serta kolesterol <200 mg/dl (Depkes RI, 2006; Kemenkes RI, 2011; Kemenkes RI, 2014). Pada keempat pemeriksaan, penduduk kampung Yapase memiliki nilai asam urat dan tekanan darah tinggi (Tabel 2). Hal ini akan berpotensi menyebabkan penyakit gout, jantung koroner, dan stroke (Setiasih dan Marfianti, 2014). Dari 18 orang penderita asam urat dilihat bahwa didominasi umur dari $>45 \mathrm{ke}$ atas. Faktor pekerjaan dan pendidikan diprediksi mempengaruhi kadar asam urat masyarakat kampung. Penderita didominasi memiliki pekerjaan sebagai IRT dan pendidikan SD. Jenis pekerjaan seseorang merupakan faktor yang menentukan kuantitas dan kualitas makanan karena jenis pekerjaan memiliki hubungan dengan pendapatan yang diterima (Suharjo 1989). Selain itu, pekerjaan juga menentukkan aktivitas fisik yang dilakukan seseorang dan alokasi waktu seseorang untuk dapat melakukan kegiatan olahraga (Fajarina, 2011). Para ibu-ibu rumah tangga biasanya lebih banyak menghabiskan waktu di rumah sehingga lebih banyak mengkonsumsi makanan. Pendidikan/ pengetahuan mempengaruhi hal ini. Umur di atas 50 tahun lebih beresiko dengan tekanan darah tinggi, asam urat, dan kolesterol (Huda, 2016).

Tabel 2. Data pemeriksaan tekanan darah, KGA, asam urat, da kolesterol pada masyarakat Yapase

masyarakat kampung tentang jenis-jenis makanan yang rendah purin yang terbatas membuat masyarakat tidak selektif memilih makanan. Faktor secara geografis yang penyebab juga dimana kampung Yapase berada di pinggir pantai dan masyarakat lebih banyak makan ikan (kerang, kepiting). Di samping itu pola konsumsi lain yaitu sering terjadi pada masyarakat adaalah memakan daging dan sayur-sayuran seperti kangkung, bayam, daun singkong yang memiliki kadar purin yang tinggi.

\section{SIMPULAN}

Skrining awal pemeriksaan tekanan darah, gula, asam urat, dan kolesterol darah diperlukan untuk menentukan faktor kesehatan seseorang. Kegiatan ini diikuti 32 peserta, sebanyak 10 orang (31\%) mengalami prehipertensi, 2 orang $(6 \%)$ mengalami hiperkolesterolemia dan 18 orang $(56 \%)$ memiliki kadar asam urat yang tinggi.

\section{UCAPAN TERIMA KASIH}

Ucapkan terima kasih disampaikan kepada DRPM KEMENRISTEK DIKTI yang telah mendanai kegiatan ini dalam bentuk Hibah Pengabdian. 


\section{DAFTAR PUSTAKA}

Charles, A. S., P. S. Wulandari, I. Maria. (2016). Pemeriksaan kadar kolesterol dan tekanan darah pada masyarakat Kota Jambi sebagai skrining awal penyakit jantung koroner. Jurnal Pengabdian pada Masyarakat. 31(4): 18-20

Dinkes RI. (2005). Pharmaceutical Care untuk Penyakit Diabetes Mellitus. Jakarta. Direktorat Bina Farmasi Komunitas dan Klinik.

Depkes RI, (2006). Pharmaceutical care untuk penyakit hipertensi. Jakarta. Direktorat Bina Farmasi Komunitas dan Klinik. Ditjen Bina Kefarmasian dan Alat Kesehatan

Fajarina, E. (2011). Analisis pola konsumsi dan pola aktivitas dengan kadar asam urat pada lansia wanita peserta pemberdayaan lansia di Bogor. Skripsi. Institut Pertanian Bogor.

Hayani, M. dan W. Widyaningsih. (2011). Efek ekstrak etanol herbal putri malu (Mimosa pudica, 1.) sebagai penurun kadar asam urat serum Mencit Jantan Galur Swiss. Prosiding Seminal Nasional Home Care. Yogyakarta: Fakultas Farmasi dan FKM Universitas Ahmad Dahlan: 29-33.

Huda, S. A. (2016). Hubungan antara kadar glukosa darah dengan tekanan darah manusia di RW 03 Kelurahan Kebayoran Lama Jakarta Selatan. Bioedukasi. 7(2): 144-150

Kemenkes RI. (2011). Pedoman interpretasi data klinik. Jakarta. Direktur Pelayanan Kefarmasian.

Kemenkes RI. (2014). Pusat data dan informasi. Situasi dan analisis Diabetes. Jakarta.
Setiasih, U. dan E. Marfianti. (2014). Hubungan antara kadar asam urat serum dengan tingkat keparahan penyakit jantung coroner di RSU PKU Muhammadiyah Yogyakarta. JKKI. 6(2): 95-101

Tayeb, R., V. Amelia, dan Usmar. (2012). Pengaruh Pemberian Infus Sarang Semut (Myrmecodia pendens) Tehadap Kadar Asam Urat Darah Pada Kelimci (Oryctolagus cuniculus). Majalah Farmasi dan Farmakologi. 16 (1): 31-36. 